\title{
Expression profile and prognostic role of sex hormone receptors in gastric cancer
}

\author{
$\mathrm{Lu} \mathrm{Gan}^{1 \dagger}$, Jian He ${ }^{1 \dagger}$, Xia Zhang ${ }^{1}$, Yong-Jie Zhang ${ }^{1}$, Guan-Zhen Yu' , Ying Chen², Jun Pan ${ }^{1}$, Jie-Jun Wang ${ }^{1 *}$ \\ and Xi Wang ${ }^{1 *}$
}

\begin{abstract}
Background: Increasing interest has been devoted to the expression and possible role of sex hormone receptors in gastric cancer, but most of these findings are controversial. In the present study, the expression profile of sex hormone receptors in gastric cancer and their clinicopathological and prognostic value were determined in a large Chinese cohort.

Methods: The mRNA and protein expression of estrogen receptor alpha (ERa), estrogen receptor beta (ERß), progesterone receptor (PR), and androgen receptor (AR) in primary gastric tumors and corresponding adjacent normal tissues from 60 and 866 Chinese gastric cancer patients was detected by real-time quantitative PCR and immunohistochemistry method, respectively. The expression profile of the four receptors was compared and their associations with clinicopathological characteristics were assessed by using Chi-square test. The prognostic value of the four receptors in gastric cancer was evaluated by using univariate and multivariate Cox regression analysis.

Results: The presence of ERa, ERB, PR, and AR in both gastric tumors and normal tissues was confirmed but their expression levels were extremely low except for the predominance of ERR. The four receptors were expressed independently and showed a decreased expression pattern in gastric tumors compared to adjacent normal tissues. The positive expression of the four receptors all correlated with high tumor grade and intestinal type, and ERa and AR were also associated with early TNM stage and thereby a favorable outcome. However, ERa and AR were not independent prognostic factors for gastric cancer when multivariate survival analysis was performed.
\end{abstract}

Conclusions: Our findings indicate that the sex hormone receptors may be partly involved in gastric carcinogenesis but their clinicopathological and prognostic significance in gastric cancer appears to be limited.

Keywords: Gastric cancer, Estrogen receptor alpha, Estrogen receptor beta, Progesterone receptor, Androgen receptor, Prognosis

\section{Background}

Hormonal therapy is one of the major modalities of systemic treatment for hormone-dependent tumors such as breast cancer and prostate cancer [1,2]. The principle of hormonal therapy is that the sex hormones, estrogen or androgen, stimulate specific hormone-dependent cancer cells to grow and spread. Deprivation on the synthesis of such hormones or blocking the hormone signaling pathways can induce tumor recession. Particularly, it is well demonstrated that the hormone receptors are pivotal

\footnotetext{
* Correspondence: jiejunwang@gmail.com; d.wangxi@gmail.com

${ }^{\dagger}$ Equal contributors

'Department of Oncology, Changzheng Hospital, Second Military Medical University, Shanghai, China

Full list of author information is available at the end of the article
}

targets for treatment of hormone-dependent tumors. Tamoxifen, an estrogen antagonist competitively binding to estrogen receptor (ER), has obtained great success in the treatment of ER-positive breast cancer in the past several decades [1-6]. The success of tamoxifen has prompted investigators to evaluate the possible role of hormone receptors in a variety of other tumors derived from "nontarget" organs and determine the possibility of hormonal therapy for these tumors, including gastric cancer $[7,8]$.

Since 1983, a few of studies have examined the expression of ER in gastric cancer. However, considerable controversy is raised as to the expression level of ER and its prognostic value in gastric cancer [9-27]. More

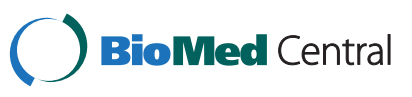


detailedly, a few studies show that ER alpha $(E R \alpha)$ is absent in gastric cancer but ER beta (ER $\beta$ ) is expressed in abundance, whereas others indicate that the two ER isoforms are both expressed [22-27]. Furthermore, some authors find ER expression is correlated with poor differentiation, advanced stage, and adverse outcome while others suggest the opposite [17,19,23,24,26,27]. Additionally, the roles of progesterone receptor (PR) and androgen receptor (AR) in gastric cancer are poorly defined [28]. In the present study, the expression profile of four sex hormone receptors, ER $\alpha, \mathrm{ER} \beta, \mathrm{PR}$, and AR, was determined in gastric tumors and corresponding normal tissues from a large Chinese cohort, and their clinicopathological and prognostic value was assessed.

\section{Methods}

\section{Patients and tissue samples}

A total of 1072 patients underwent gastrectomy for histopathologically confirmed gastric carcinoma in Changhai Hospital, Second Military Medical University, Shanghai, China, from 2000 through 2005. Patients without sufficient tissue samples or necessary clinicopathological information, or patients suffered from double primary tumors or remnant gastric cancer, or those died within two months of surgery, were all excluded and thus 866 eligible patients were enrolled. The patients were followed up every 6 months until death or study end (March 30 2010), except for those lost to follow-up. The tumor tissues and their adjacent normal tissues from these patients were routinely fixed in $10 \%$ buffered formalin and blocked in paraffin, ready to tissue microarray construction. In addition, 60 pairs of fresh gastric tumors and their matched normal mucosa were obtained. The fresh tissue samples were prepared carefully within $15 \mathrm{~min}$ of excision, stabilized in RNAlater ${ }^{\circledR}$ solution (Ambion, Austin, TX, USA) at $4^{\circ} \mathrm{C}$ overnight and preserved at $-20^{\circ} \mathrm{C}$ until RNA extraction. All patients enrolled were naïve for any anticancer therapy. All tissue specimens were obtained with patient informed consent, and the protocol was approved by Institutional Review Board of Second Military Medical University.

\section{Total RNA preparation and reverse transcription}

Total RNA was extracted from the RNAlater ${ }^{\circledR}$-stabilized tissue samples using an RNAqueous ${ }^{\circledR}$-4PCR kit (Cat\# AM1914, Ambion, Austin, TX, USA) according to the manufacturer's protocol. Complementary DNA (cDNA) was synthesized from total RNA with use of a High Capacity cDNA Reverse Transcription Kit (PN4374966, Applied Biosystems, Foster City, CA), according to the manufacturer's instructions. The reaction was incubated in an ABI 2720 Thermocycler (Applied Biosystems) for $10 \mathrm{~min}$ at $25^{\circ} \mathrm{C}, 120 \mathrm{~min}$ at $37^{\circ} \mathrm{C}$, and $5 \mathrm{~min}$ at $85^{\circ} \mathrm{C}$.
cDNA samples were stored at $-20^{\circ} \mathrm{C}$ before real-time PCR amplification.

\section{Real-time quantitative PCR}

Real-time quantitative PCR was performed with an ABI PRISM $^{\circledR}$ 7900HT Sequence Detection System (Applied Biosystems) using the Power SYBR ${ }^{\circledR}$ Green PCR Master Mix kit (PN4367659, Applied Biosystems) as described by the manufacturer. A total reaction volume of $50 \mu \mathrm{l}$ contained $5 \mu \mathrm{l}$ of cDNA template corresponding to $100 \mathrm{ng}$ of total RNA, $25 \mu \mathrm{l}$ of $2 \times$ Power SYBR $^{\circledR}$ Green PCR Master Mix, $1 \mu \mathrm{l}$ forward primer of $10 \mu \mathrm{M}, 1 \mu \mathrm{l}$

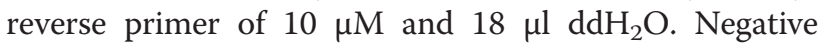
controls included water instead of cDNA in the PCR reaction and addition of RNA instead of cDNA, and $\beta$-actin was used as an endogenous control. The primer sequences were as follows: ER $\alpha$ 5'-TCCTGATGAT TGGTCTCGTCT- $3^{\prime}$ (forward) and $5^{\prime}$-ACATTTTCCCT GGTTCCTGTC- $3^{\prime}$ (reverse), ER $\beta$ 5'-AGTCTGGTCGT GTGAAGGATG-3' (forward) and $5^{\prime}$-ACTTCTCTGTC TCCGCACAAG-3' (reverse), PR 5'-ACACCTCCAGTT CTTTGCTGAC-3' (forward) and $5^{\prime}$-ATTCTTTCAT CCGCTGTTCATT-3' (reverse), AR 5'-ATTGTCCAT CTTGTCGTCTTCG-3' (forward) and $5^{\prime}$-AGCCTCTC CTTCCTCCTGTAGT- $3^{\prime}$ (reverse), and $\beta$-actin $5^{\prime}$-TGT TACAGGAAGTCCCTTGC- $3^{\prime}$ (forward) and $5^{\prime}$-AAGC AATGCTATCACCTCCC-3' (reverse). All primers were synthesized by Sangon Biotech Co. Ltd., Shanghai, China. The amplification was run at $95^{\circ} \mathrm{C}$ for 10 min followed by 40 cycles of $95^{\circ} \mathrm{C}$ for $15 \mathrm{sec}$ and $60^{\circ} \mathrm{C}$ for $1 \mathrm{~min}$. All samples were run in triplicate, and data were analyzed by use of the Sequence Detection System (SDS) Software Version 2.3 (Applied Biosystems). The specificity of amplification reaction was confirmed by analyzing the corresponding dissociation curves. The quantification of sex hormone receptors was normalized to $\beta$-actin expression using the $2^{-\Delta \Delta \mathrm{Ct}}$ method.

\section{Tissue microarray construction and immunohistochemistry}

Tissue microarrays were constructed from formalinfixed and paraffin-embedded archival tissue blocks using a tissue arrayer (Beecher Instruments, Silver Spring, MD) according to the previous description [29,30]. For each of 866 patients, duplicate gastric tumor cylinders and at least one matched adjacent normal mucosa cylinder with a diameter of $1.5 \mathrm{~mm}$ were arrayed and consecutive $4 \mu \mathrm{m}$ sections were cut. Immunohistochemistry assay for ER $\alpha, E R \beta, P R$, and AR was performed using an UltraSensitive $^{\text {th }}$ SP kit (\#9710, Maixin, Fuzhou, China) according to the manufacturer's instructions. Briefly, the tissue microarray sections were deparaffinized in xylene, rehydrated with graded ethanol, and subjected to antigen retrieval in citrate buffer $(\mathrm{pH}$ 6.0) in a high-pressure 
cooker. The sections were subsequently blocked for endogenous peroxide activity with $3 \%$ hydrogen peroxide, treated with preimmune goat serum to block nonspecific binding sites, and then incubated with the primary mouse monoclonal antibodies against ER $\alpha$ (clone 33, ab2746, Abcam; 1:50), ER $\beta$ (clone 14C8, ab288, Abcam; 1:100), PR (clone PR-AT 4.14, ab2764, Abcam; 1:100), and AR (clone AR 441, ab9474, Abcam; 1:200), respectively. After an overnight incubation at $4^{\circ} \mathrm{C}$, the sections were washed and incubated with a secondary biotinylated anti-mouse/rabbit antibody. The immunostaining was visualized with a diaminobenzidine detection kit (DAB-0031, Maixin) and then the sections were counterstained with hematoxylin, dehydrated, cleared, and coverslipped. Human breast cancer tissue overexpressing ER $\alpha$, ER $\beta$, and PR, and prostate cancer tissue overexpressing AR were used as positive controls. Sections incubated without primary antibody were also included in each staining experiment as negative controls.

\section{Evaluation of immunostaining}

Brown cytoplasmic and/or nuclear staining in the gastric cancer cells or adjacent normal epitheliums was considered to be positive. The signal was quantified by the Allred score system which represented the estimated intensity and proportion of positive-staining cells [31]. A score $\geq 3$ was designated as positive expression and a score of 0 or 2 was regarded as negative. The immunostaining sections were viewed by two pathologists independently using an Olympus CX31 microscope (Olympus, Japan).

\section{Statistical analysis}

The expression difference of sex hormone receptors between gastric tumors and corresponding normal tissues was determined by the Wilcoxon matched-pairs signed-rank test or Chi-square test where appropriate. Correlations were computed using the Spearman rank test. The associations between expression of sex hormone receptors and clinicopathological characteristics were tested using Chi-square test. The probability of survival was estimated by Kaplan-Meier method and compared by log-rank test. The prognostic role of sex hormone receptors in gastric cancer was identified using univariate and multivariate Cox model. All $P$ values were two-sided and less than 0.05 was considered statistically significant. Statistical analyses were performed by the SPSS 15.0 for windows (SPSS, Chicago, IL, USA).

\section{Results}

\section{Expression profile of sex hormone receptors in} gastric cancer

Real-time quantitative PCR showed that the mRNAs of $E R \alpha, E R \beta, P R$ and $A R$ were all detected in all 60 pairs of gastric tumors and their matched normal mucosa. Furthermore, the mRNA levels of the four receptors in gastric tumors were all significantly decreased compared to those in their matched normal mucosa (Figure 1).

Immunohistochemistry assay based on 866 Chinese patients further demonstrated the expression of ER $\alpha$, $E R \beta, P R$ and AR proteins. Unlike the typical nuclear expression in breast and prostate cancer tissues as positive controls (see Additional file 1: Figure S1), the four sex hormone receptors all presented a cytoplasmic/ nuclear staining pattern (Figure 2). However, ER $\alpha, P R$ and AR immunostaining was mainly localized in the cytoplasm while ER $\beta$ immunostaining was ubiquitously observed in the nucleus for both normal epithelium and gastric cancer cells (Figure 2). After exclusion of inevaluable cases due to tissue loss or inadequate tissue, the positive rates of ER $\alpha, E R \beta, P R$ and AR expression in normal tissues were $38.3 \%, 97.3 \%, 30.5 \%$, and $52.7 \%$, and the positive rates of the four receptors in gastric tumor were $12.0 \%, 91.9 \%, 23.3 \%$, and $33.0 \%$, respectively. The protein level of each receptor in gastric tumor was all significantly lower than that expressed in normal gastric mucosa $(P<0.001)$.

\section{Correlations among expression of sex hormone receptors in gastric cancer}

Table 1 shows the Spearman correlations among expression of the four sex hormone receptors on mRNA and protein levels. Strong correlations of mRNA expression between ER $\alpha$ and ER $\beta, E R \alpha$ and PR, and ER $\beta$ and PR were revealed, while no significant correlations between $\mathrm{AR}$ and the other three receptors were detected. On protein level, significant correlations were observed in all pairwise comparison among immunostaining scores of the four receptors. However, these correlation coefficients were so small $(r<0.4)$ that only extremely weak correlations among the four receptors were found.

\section{ERa and AR expression correlates with tumor grade, Lauren type, and TNM stage of gastric cancer}

Possible associations of ER $\alpha, E R \beta, P R$ and AR expression with available clinicopathological characteristics of 866 gastric cancer patients are presented in Table 2. The protein expression of ER $\alpha$ and AR was closely associated with tumor grade, Lauren type, $\mathrm{T}$ classification, and $\mathrm{N}$ classification $(P<0.001)$, respectively, and consequently correlated with TNM stage $(P<0.001)$. Importantly, positive staining of ER $\alpha$ and $A R$ was more frequently observed in patients with better differentiated tumors, intestinal type, and earlier TNM stage. Either for ER $\beta$ or for PR, only correlations between the positivity and the tumor grade and Lauren type were noticed $(P<0.05)$. No significant associations were found 

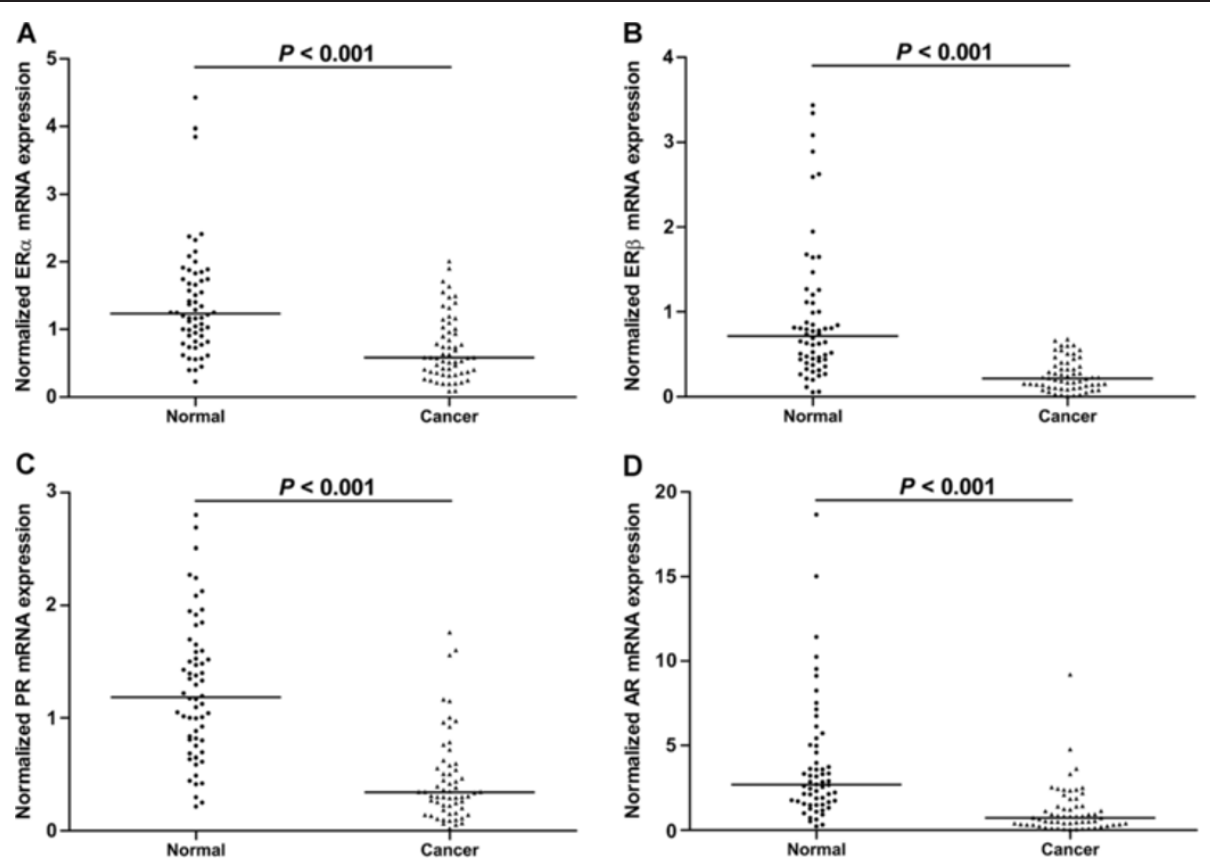

Figure 1 Scatter plots of (A) ERa, (B) ER $\beta$, (C) PR, and (D) AR mRNA levels in gastric tumors and corresponding adjacent normal mucosa $(\boldsymbol{n}=\mathbf{6 0})$. The line indicates the median value. The mRNA levels were normalized to $\beta$-actin and statistical differences were determined using Wilcoxon matched-pairs signed-rank test.

between expression of ER $\beta$ and PR and other clinicopathological characteristics.

\section{ERa and AR expression correlates with favorable outcome in patients with gastric cancer}

Table 3 reports the findings from univariate and multivariate survival analysis in gastric cancer. Univariate analysis showed that the significant prognostic factors included age, tumor size, tumor grade, Lauren type, $\mathrm{T}$ classification, $\mathrm{N}$ classification, radical resection, TNM stage, ER $\alpha$ expression, and AR expression. For ER $\alpha-$ positive patients, the 5-year survival rate and median survival were $71.3 \%(95 \% \mathrm{CI}, \quad 62.5 \%-80.1 \%)$ and 81.5 months (range, 4-121 months), compared with 50.7\% (95\% CI, 47.0\%-54.4\%) and 43.0 months (range, 2-123 months) for ER $\alpha$-negative patients, respectively. ER $\alpha$-positive patients had a significantly better outcome than ER $\alpha$-negative patients $(P<0.001$; Figure $3 \mathrm{~A})$. The expression of ER $\beta$ and PR was not associated with the prognosis of gastric cancer patients $(P=0.568$ for ER $\beta$ and $P=0.385$ for PR; Figure $3 \mathrm{~B}$ and $3 \mathrm{C}$ ). For patients with AR-positive tumors, the 5-year survival rate was $59.4 \%(95 \%, 53.5 \%-65.3 \%)$ with a median survival of 71.0 months (range, 2-123 months), which took significant advantage over a 5-year survival rate of $49.7 \%$ (95\% CI, 45.6\%-53.8\%) with a median survival of 40.0 months (range, 2-123 months) for patients with AR-negative tumors $(P=0.028$; Figure 3D). However, only age, tumor size, $\mathrm{T}$ classification, $\mathrm{N}$ classification, and radical resection were retained in the multivariate Cox model, as shown in Table 3. The expression of ER $\alpha$ and AR were not independent prognostic factors for gastric cancer.

\section{Discussion}

In the present study, the expression profile and prognostic role of $E R \alpha, E R \beta, P R$, and AR in gastric cancer was determined in a large Chinese cohort. Our results showed that the four receptors were all expressed with decreased abundance in gastric tumors compared to adjacent normal tissues. All the four receptors were associated with high tumor grade and intestinal type, and the positive expression of ER $\alpha$ and AR also correlated with early TNM stage and thereby a favorable outcome.

Our findings are inconsistent with a few previous publications in which ER $\alpha$, PR and AR were proposed as adverse factors whereas ER $\beta$ was deemed beneficial for gastric cancer patients [19,26-28]. Factually, substantial disagreement has been observed for several decades with regard to the expression and role of sex hormone receptors in gastric cancer. The conflicting findings may be partly attributed to heterogeneity in experimental methods, positivity criteria, sample size, and patient ethnicity. In particular, by various methods, the expression levels of sex hormone receptors even their presence, varies in a large range in gastric cancer. Furthermore, most of these investigations usually suffer from very small sample size and as a result, the conclusions on clinicopathological significance of sex hormone receptors in 


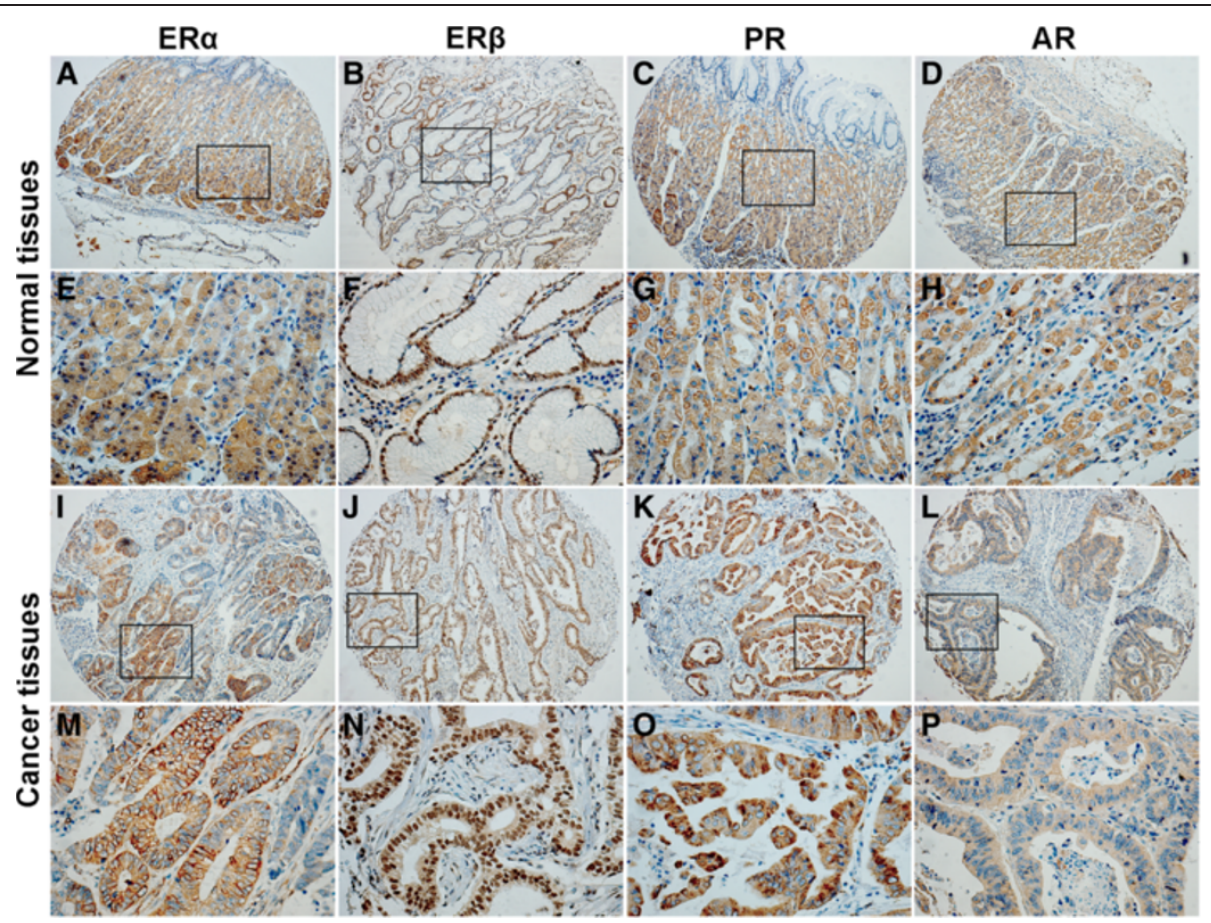

Figure 2 Representative immunostaining of sex hormone receptors in gastric tumors and corresponding adjacent normal tissues. Positive staining of $(\mathbf{A}, \mathbf{E}) E R a,(\mathbf{B}, \mathbf{F}) E R \beta,(\mathbf{C}, \mathbf{G}) P R$, and $(\mathbf{D}, \mathbf{H})$ AR in normal tissues, and positive staining of $(\mathbf{I}, \mathbf{M}) E R a,(\mathbf{J}, \mathbf{N}) E R \beta,(\mathbf{K}, \mathbf{O}) P R$, and $(\mathbf{L}, \mathbf{P})$ AR in gastric tumors is shown. Original magnification, $\times 100$ for $(\mathbf{A})$ through $(\mathbf{D})$ and $(\mathbf{I})$ through $(\mathbf{L}) ; \times 400$ for $(\mathbf{E})$ through $(\mathbf{H})$ and $(\mathbf{M})$ through $(\mathbf{P})$.

gastric cancer are often contradictory. Additionally, the failure to distinguish $E R \beta$ from ER $\alpha$ in earlier reports also contributes to conflicting results for ER.

To minimize the above-mentioned limitations, in this study, the expression of the four receptors was detected simultaneously at both mRNA and protein levels. More importantly, a set of tissue microarray containing tumors and corresponding normal tissues from 866 Chinese patients was employed. The largest sample size to date and the high uniformity of experimental conditions profiting from tissue microarray made our results more reliable and convincing.

Table 1 Correlations among expression of sex hormone receptors in gastric cancer

\begin{tabular}{lccccc}
\hline Correlation & \multicolumn{2}{c}{ mRNA expression } & & \multicolumn{2}{c}{ Protein expression } \\
\cline { 2 - 3 } & $\boldsymbol{r}$ & $\boldsymbol{P}$ & & $\boldsymbol{r}$ & $\boldsymbol{P} \boldsymbol{P}$ \\
\hline ERa vs ERß & 0.795 & $<0.001$ & & 0.136 & $<0.001$ \\
ERa vs PR & 0.756 & $<0.001$ & & 0.083 & 0.016 \\
ERa vs AR & 0.328 & 0.437 & & 0.171 & $<0.001$ \\
ERß vs PR & 0.714 & $<0.001$ & & 0.132 & $<0.001$ \\
ERß vs AR & 0.492 & 0.231 & & 0.329 & $<0.001$ \\
PR vs AR & 0.186 & 0.734 & & 0.098 & 0.005 \\
\hline
\end{tabular}

$E R a$, estrogen receptor alpha; $E R \beta$, estrogen receptor beta; $P R$, progesterone receptor; $A R$, androgen receptor; $r$, Spearman rank correlation coefficients. †Spearman rank correlation test.
Owing to the well establishment in breast cancer, ERs also are the best-studied sex hormone receptors in gastric cancer. Using a semi-quantitative RT-PCR, ER $\beta$ has shown a more preferential expression pattern than ER $\alpha$ in both gastric tumors and normal mucosa. Compared to the expression in normal gastric mucosa, ER $\alpha$ tends to increase in tumor tissues while ER $\beta$ declines [23,24]. With a real-time quantitative PCR, the presence of ER $\alpha$ and ER $\beta$ mRNA in all tumors and normal mucosa samples was demonstrated in our study. Moreover, the significant decrease of both ER $\alpha$ and ER $\beta$ mRNAs in tumors compared to in normal tissues was indicated, similar to the findings in another study from China [26].

Various expression patterns of ER $\alpha$ and ER $\beta$ proteins have been observed by several investigations. By IHC, a few studies have found no or sporadic staining of $E R \alpha$ in gastric tumors even in matched normal tissues, while strong ER $\beta$ staining in both cancer and their noncancerous tissues $[22,24,27,28]$. Our results are not quite similar to these findings. ER $\alpha$ protein is indeed expressed in both normal mucosa (38.3\%) and gastric tumors $(12.0 \%)$ but with a very weak pattern, while ER $\beta$ protein is the predominant isoform of ER in both normal (97.3\%) and cancerous (91.9\%) tissues. Both ER $\alpha$ and ER $\beta$ proteins present a decreased expression pattern in gastric tumors compared to their corresponding normal tissues [26]. 
Table 2 Association between expression of sex hormone receptors and clinicopathological characteristics in gastric cancer

\begin{tabular}{|c|c|c|c|c|c|c|c|c|c|}
\hline \multirow[t]{3}{*}{ Variable } & \multirow{3}{*}{$\begin{array}{l}\text { Total patients } \\
(n=866)\end{array}$} & \multicolumn{8}{|c|}{ Evaluable patients $\dagger$} \\
\hline & & \multicolumn{2}{|c|}{$\operatorname{ERa}(n=848)$} & \multicolumn{2}{|c|}{$\operatorname{ER} \beta(n=823)$} & \multicolumn{2}{|l|}{ PR $(n=851)$} & \multicolumn{2}{|c|}{$\operatorname{AR}(n=843)$} \\
\hline & & Positive No. (\%) & $P \neq$ & Positive No. (\%) & $P \neq$ & Positive No. (\%) & $P \neq$ & Positive No. (\%) & $P \neq$ \\
\hline Sex & & & 0.496 & & 0.166 & & 0.522 & & 0.313 \\
\hline Female & 261 & $29(10.9)$ & & $221(89.8)$ & & $58(21.9)$ & & $81(30.6)$ & \\
\hline Male & 605 & $73(12.5)$ & & $535(92.7)$ & & $140(23.9)$ & & $197(34.1)$ & \\
\hline Age, years & & & 0.837 & & 0.187 & & 0.523 & & 0.254 \\
\hline$\leq 40$ & 70 & $6(8.8)$ & & $57(87.7)$ & & $12(17.6)$ & & $16(24.2)$ & \\
\hline$\leq 50$ & 148 & $19(13.2)$ & & $126(93.3)$ & & $30(20.7)$ & & $46(32.2)$ & \\
\hline$\leq 65$ & 328 & $39(12.0)$ & & $283(90.1)$ & & $79(24.5)$ & & $102(31.9)$ & \\
\hline$>65$ & 320 & $38(12.2)$ & & $290(93.9)$ & & $77(24.4)$ & & $114(36.3)$ & \\
\hline Tumor site§ & & & 0.839 & & 0.700 & & 0.433 & & 0.605 \\
\hline Upper & 138 & 19 (13.8) & & $123(91.8)$ & & $25(18.2)$ & & $52(38.0)$ & \\
\hline Middle & 263 & $30(11.8)$ & & $224(90.3)$ & & $63(24.3)$ & & $81(31.9)$ & \\
\hline Lower & 416 & $46(11.3)$ & & $368(92.9)$ & & $100(24.6)$ & & $129(32.0)$ & \\
\hline Diffuse & 49 & $7(14.3)$ & & 41 (91.1) & & $10(20.4)$ & & $16(32.7)$ & \\
\hline Tumor size, cm & & & 0.166 & & 0.316 & & 0.425 & & 0.127 \\
\hline$\leq 2$ & 133 & $22(17.1)$ & & $117(95.9)$ & & $28(22.0)$ & & $52(42.3)$ & \\
\hline$\leq 3$ & 160 & $21(13.7)$ & & 134 (89.9) & & $29(18.6)$ & & $50(32.3)$ & \\
\hline$\leq 5$ & 273 & $30(11.1)$ & & $243(91.7)$ & & $67(24.7)$ & & 84 (31.3) & \\
\hline$>5$ & 300 & $29(9.8)$ & & $262(91.3)$ & & $74(24.9)$ & & $92(31.0)$ & \\
\hline Tumor grade & & & $<0.001$ & & 0.030 & & 0.001 & & $<0.001$ \\
\hline Well & 48 & 15 (31.9) & & $53(96.4)$ & & $19(40.4)$ & & $22(48.9)$ & \\
\hline Moderate & 286 & $47(16.5)$ & & $274(94.5)$ & & 77 (27.1) & & 127 (44.9) & \\
\hline Poor & 532 & $40(7.8)$ & & $429(89.7)$ & & 102 (19.6) & & $129(25.0)$ & \\
\hline Lauren type & & & 0.012 & & 0.010 & & 0.017 & & $<0.001$ \\
\hline Intestinal & 535 & $76(14.4)$ & & 481 (93.0) & & $139(26.3)$ & & 197 (37.6) & \\
\hline Diffuse & 297 & $21(7.4)$ & & $250(91.2)$ & & 55 (19.0) & & $68(23.9)$ & \\
\hline Mixed & 34 & $5(14.7)$ & & $25(78.1)$ & & $4(11.8)$ & & $13(38.2)$ & \\
\hline T classification & & & $<0.001$ & & 0.195 & & 0.818 & & $<0.001$ \\
\hline pT1 & 132 & $33(26.0)$ & & $114(95.0)$ & & $28(21.7)$ & & $61(48.8)$ & \\
\hline pT2 & 142 & 19 (13.9) & & $125(94.7)$ & & $36(26.3)$ & & 49 (36.6) & \\
\hline pT3 & 528 & $44(8.4)$ & & $463(90.8)$ & & $120(23.0)$ & & $147(28.2)$ & \\
\hline pT4 & 64 & $6(9.7)$ & & $54(88.5)$ & & $14(22.2)$ & & $21(33.9)$ & \\
\hline N classification & & & $<0.001$ & & 0.574 & & 0.340 & & 0.001 \\
\hline pNo & 309 & $67(22.3)$ & & $272(93.2)$ & & $76(25.0)$ & & $125(41.9)$ & \\
\hline $\mathrm{pN} 1$ & 314 & $20(6.5)$ & & $275(90.2)$ & & $63(20.7)$ & & $85(28.0)$ & \\
\hline $\mathrm{pN} 2$ & 191 & $13(6.9)$ & & $165(92.7)$ & & $43(22.6)$ & & $52(27.4)$ & \\
\hline $\mathrm{pN3}$ & 52 & $2(3.9)$ & & 44 (91.7) & & 16 (30.8) & & $16(31.4)$ & \\
\hline TNM stageq & & & $<0.001$ & & 0.173 & & 0.535 & & $<0.001$ \\
\hline I & 187 & $44(24.4)$ & & $165(95.4)$ & & $48(26.2)$ & & 85 (47.8) & \\
\hline$\|$ & 158 & $21(13.5)$ & & $138(90.8)$ & & 39 (25.3) & & $53(35.1)$ & \\
\hline III & 294 & $23(8.0)$ & & $253(89.7)$ & & $61(21.0)$ & & $74(25.3)$ & \\
\hline IV & 227 & $14(6.3)$ & & $200(92.6)$ & & $50(22.3)$ & & 66 (29.7) & \\
\hline
\end{tabular}

$E R a$, estrogen receptor alpha; $E R \beta$, estrogen receptor beta; $P R$, progesterone receptor; $A R$, androgen receptor. + Total patients except for inevaluable cases due to tissue loss or inadequate tissue in immunohistochemistry assay. ¥Chi-square test. §Japanese Classification of Gastric Carcinoma (3rd English edition) proposed by the Japanese Gastric Cancer Association (JGCA). IThe 6th TNM Classification of Malignant Tumors proposed by the AJCC/UICC. 
Table 3 Univariate and multivariate analysis of overall survival by Cox model in gastric cancer

\begin{tabular}{|c|c|c|c|c|c|c|}
\hline \multirow[t]{2}{*}{ Variable } & \multicolumn{3}{|c|}{ Univariate cox } & \multicolumn{3}{|c|}{ Multivariate cox } \\
\hline & $\mathrm{HR}$ & $95 \% \mathrm{Cl}$ & $P$ & $\mathrm{HR}$ & $95 \% \mathrm{Cl}$ & $P$ \\
\hline Sex: female vs male & 0.896 & $0.728-1.103$ & 0.302 & & & \\
\hline Age, years: $\leq 40$ vs $\leq 50$ vs $\leq 65$ vs $>65$ & 1.262 & $1.127-1.412$ & $<0.001$ & 1.226 & $1.089-1.379$ & 0.001 \\
\hline Tumor site: upper vs middle vs lower vs diffuset & 0.998 & $0.883-1.128$ & 0.976 & & & \\
\hline Tumor size, $\mathrm{cm}: \leq 2$ vs $\leq 3$ vs $\leq 5$ vs $>5$ & 1.590 & $1.434-1.764$ & $<0.001$ & 1.149 & $1.023-1.291$ & 0.019 \\
\hline Tumor grade: well vs moderate vs poor & 1.540 & $1.287-1.841$ & $<0.001$ & 1.191 & $0.959-1.481$ & 0.114 \\
\hline Lauren type: intestinal vs diffuse vs mixed & 1.202 & $1.020-1.415$ & 0.028 & 1.143 & $0.945-1.383$ & 0.167 \\
\hline T classification: pT1 vs pT2 vs pT3 vs pT4 & 2.135 & $1.859-2.451$ & $<0.001$ & 1.490 & $1.263-1.757$ & $<0.001$ \\
\hline N classification: pN0 vs pN1 vs pN2 vs pN3 & 2.237 & $2.017-2.481$ & $<0.001$ & 1.733 & $1.543-1.947$ & $<0.001$ \\
\hline Radical resection: yes vs no & 3.337 & $2.706-4.114$ & $<0.001$ & 2.053 & $1.641-2.570$ & $<0.001$ \\
\hline TNM stage: | vs || vs ||| vs IV $\ddagger \S$ & 2.306 & $2.064-2.576$ & $<0.001$ & & & \\
\hline ERa: positive vs negative & 1.990 & $1.380-2.871$ & $<0.001$ & 1.159 & $0.797-1.685$ & 0.441 \\
\hline ERß: positive vs negative & 1.107 & $0.779-1.573$ & 0.572 & & & \\
\hline PR: positive vs negative & 0.905 & $0.723-1.135$ & 0.389 & & & \\
\hline AR: positive vs negative & 1.265 & $1.023-1.564$ & 0.030 & 1.072 & $0.858-1.340$ & 0.541 \\
\hline
\end{tabular}

$H R$, hazard ratio; $C l$, confidence interval; $E R a$, estrogen receptor alpha; $E R \beta$, estrogen receptor beta; $P R$, progesterone receptor; $A R$, androgen receptor. $\dagger$ Japanese Classification of Gastric Carcinoma (3rd English edition) proposed by the Japanese Gastric Cancer Association (JGCA). ¥The 6th TNM Classification of Malignant Tumors proposed by the AJCC/UICC. §TNM stage was not included into multivariate Cox model to avoid repetition with T and N classifications.

The presence of $\mathrm{PR}$ is detected in gastric cancer as early as ER, and the positive expression of $P R$ ranges from none to all $[9,10,12-21]$. As far as AR is concerned, very little attention has been paid to AR in gastric cancer. Following the first detection of AR in 2 of 16 gastric cancer patients, a positive rate of $17.4 \%$ for AR nuclear staining in an immunohistochemical study of 86 cases was indicated [12,28]. In the present study, our results show a positive rate of $30.5 \%$ in normal mucosa and $23.3 \%$ in gastric tumors for $\mathrm{PR}$, and $52.7 \%$ in normal tissues and $33.0 \%$ in tumors for AR.

When the localization of the four sex hormone receptors is concerned, a few earlier studies have revealed that they were solely expressed in the nuclei of gastric cancer cells [22,28]. However, a few recent studies also reported a cytoplasmic staining of ER $\alpha$ and a cytoplasmic/nuclear staining of ER $\beta$ in gastric cancer [26,27]. In the present study, unlike the typical nuclear expression in breast and prostate cancer tissues as positive controls (see Additional file 1: Figure S1), the four sex hormone receptors all presented a cytoplasmic/nuclear staining pattern (Figure 2). Particularly, ER $\alpha$, PR and AR immunostaining was mainly localized in the cytoplasm while ER $\beta$ immunostaining was mostly detected in the nuclei.

Although our findings provided added information to the localization of sex hormone receptors in gastric cancer, agreement on the immunostaining location could not be finalized yet. Factually, the immunostaining location might be affected by the characteristics of antibody to some extent. In particular, different antibodies obtained from various clones usually result in inconsistent findings. For example, a sole nuclear immunostaining of ER $\alpha$ was observed with a mouse monoclonal antibody (clone ER88) [28] while a cytoplasmic expression pattern of ER $\alpha$ was detected with another mouse monoclonal antibody (clone 1D5) [26]. For ER $\beta$, a sole nuclear expression was noticed with the use of a mouse monoclonal antibody (clone 14C8) [26] while with another mouse monoclonal antibody (clone PPG5/10), a cytoplasmic/nuclear expression was identified [27]. Therefore, it would be ideal to examine the immunostaining of the four sex hormone receptors synchronously by using a wide panel of antibodies obtained from various clones as many as possible. In the present study, only a single antibody for each receptor was used and the absence of other antibodies produced from various clones was the main limitation.

Nevertheless, based on the currently available evidence, the nuclear and cytoplasmic immunostaining patterns might indicate two different functional forms of sex hormone receptors in gastric cancer which were presumed to be dependent on the specific status of cancer cells. Seeing that the cytoplasmic expression of ER $\alpha$ and ER $\beta$ has also been observed in non-small cell lung cancer $[32,33]$, the cytoplasmic expression of sex hormone receptors in these tumors derived from "nontarget" organs might suggest an independent or a novel mechanism involving in tumorigenesis distinct from the genomic signaling via nuclear forms typically occurred in breast cancer [33]. Certainly, more studies by use of 


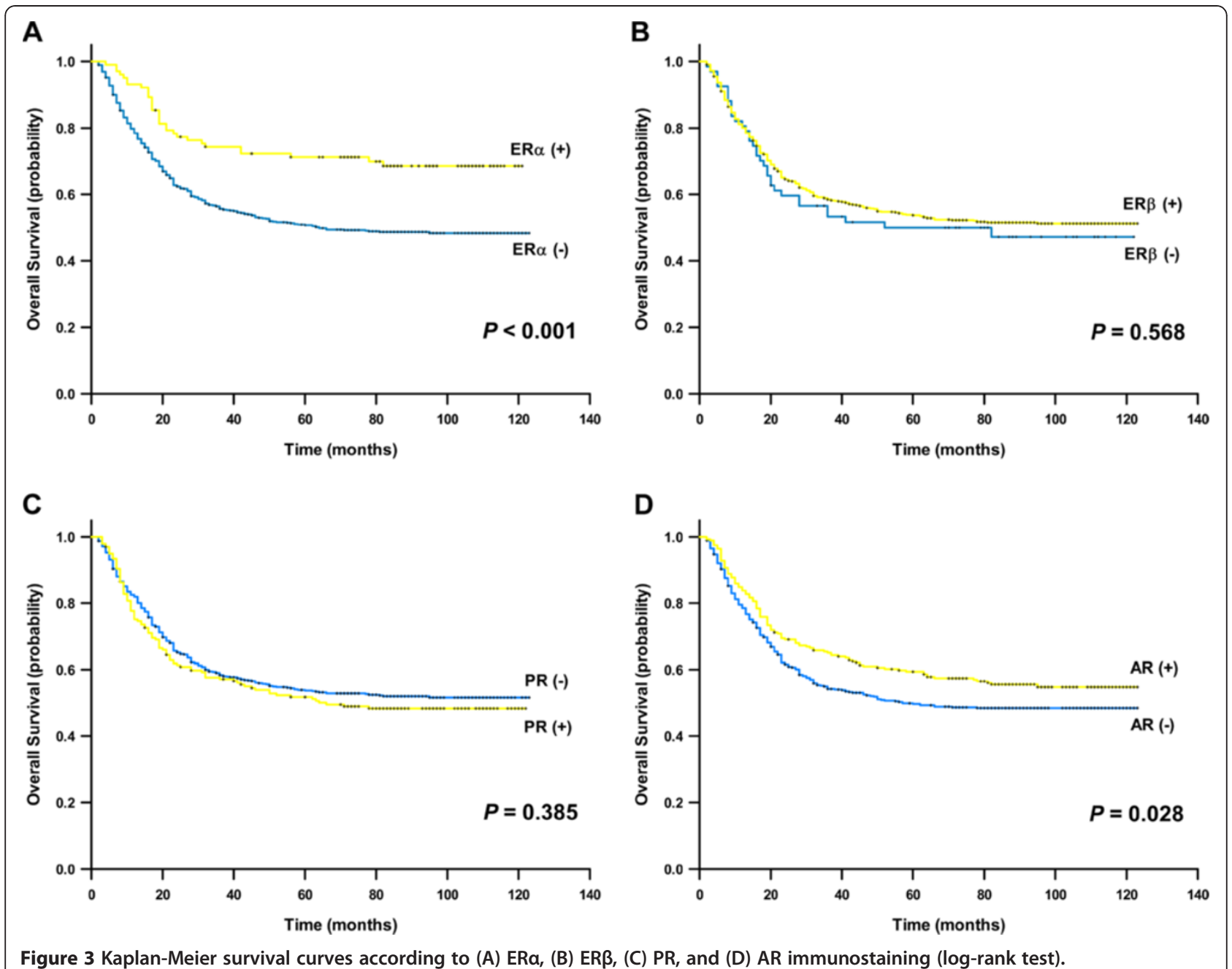

novel antibody technology and special experimental techniques are warranted to carefully verify all of these assumptions in the future.

The associations between sex hormone receptors and clinicopathological factors of gastric tumors have been studied extensively. One of the most concerns is the expression difference of sex hormone receptors in both genders which might be a possible interpretation of male predominance among gastric cancer patients [34]. However, no significant difference is found between male and female patients in this study though slight higher positive rates in male patients are observed (Table 2), which suggested that the sex difference of gastric cancer incidence cannot attributed to sex hormone receptors at least.

In this study, the expression of four hormone receptors is all closely associated with tumor grade and Lauren type. Moreover, the positive immunostaining always indicates a high tumor differentiation and intestinal type (Table 2), and the positive rates of the four receptors in normal tissues are always significantly higher than that in corresponding tumors. Given sex hormone receptors are critical effectors of normal cell growth and differentiation, it is logical to assume that these receptors are also involved in the physiological maintenance of differentiation and function of gastric mucosa [35]. Together with the findings that sex hormone-receptor-negative tumors have a higher proliferative activity than sex hormonereceptor-positive tumors in human gastrointestinal tract adenocarcinomas [16], the abnormal expression or function of these receptors may be implicated in the pathogenesis of gastric cancer to some extent [5-7].

Besides tumor grade and Lauren type, the positivity of $\mathrm{ER} \alpha$ and AR proteins also negatively correlates with advanced $\mathrm{T}$ and $\mathrm{N}$ classifications, and thereby correlates with an early TNM stage significantly (Table 2). Just as we expected, positive expression of ER $\alpha$ and AR correlates with favorable outcome for gastric cancer patients though they are not independent prognostic factors (Table 3). When ER $\beta$ and PR are concerned, no 
significant correlations are found between their expression and any clinicopathological characteristics except for tumor grade and Lauren type. Under this circumstance, the prognostic importance of ER $\beta$ and PR in gastric cancer is weak. In fact, so do our findings in the present study.

\section{Conclusion}

Our results confirmed the presence of ER $\alpha, E R \beta, P R$, and $\mathrm{AR}$ in both gastric tumors and normal mucosa but their expression levels were extremely low except for the predominance of ER $\beta$. The decreased expression pattern of the four receptors in gastric tumors and their associations with clinicopathological characteristics as well as overall survival indicate that the sex hormone receptors may be partly involved in gastric carcinogenesis. Together with the independent expression of the four receptors (Table 1) and the failure of hormone therapy for gastric cancer [36], the function and significance of sex hormone receptors in gastric cancer appears to be limited.

\section{Additional file}

Additional file 1: Figure S1. Typical nuclear immunostaining of sex hormone receptors in breast and prostate cancer tissues as positive controls. Positive nuclear staining of (A) ERa, (B) ERB, and (C) PR in breast cancer tissues, and positive nuclear staining of (D) AR in prostate cancer tissue is shown. Original magnification, $\times 400$.

\section{Competing interests}

The authors declare that they have no competing interests.

\section{Authors' contributions}

LG and $\mathrm{JH}$ performed experimental procedures, analyzed the data and drafted the manuscript. XZ, YJZ, GZY, YC, and JP performed experimental procedures, analyzed the data and reviewed the manuscript. JJW and XW designed the study, analyzed the data and drafted the manuscript. All authors read and approved the final manuscript.

\section{Acknowledgments}

This work was supported in part by Grant No. 2006BAl02A05 from the National Key Technology R\&D Program of China and Grants No. 30973432 and 81000983 from the National Natural Science Foundation of China.

\section{Author details}

${ }^{1}$ Department of Oncology, Changzheng Hospital, Second Military Medical University, Shanghai, China. 'Department of Pathology, Changhai Hospital, Second Military Medical University, Shanghai, China.

Received: 8 August 2012 Accepted: 28 November 2012

Published: 2 December 2012

\section{References}

1. Hurvitz SA, Pietras RJ: Rational management of endocrine resistance in breast cancer: a comprehensive review of estrogen receptor biology, treatment options, and future directions. Cancer 2008, 113:2385-2397.

2. Ramirez ML, Keane TE, Evans CP: Managing prostate cancer: the role of hormone therapy. Can J Urol 2007, 14(Suppl 1):10-18.

3. Hayashi $\mathrm{S}$, Yamaguchi Y: Estrogen signaling pathway and hormonal therapy. Breast Cancer 2008, 15:256-261.

4. Osborne CK, Schiff R: Mechanisms of endocrine resistance in breast cancer. Annu Rev Med 2011, 62:233-247.
5. Thomas C, Gustafsson J $\AA$ : The different roles of ER subtypes in cancer biology and therapy. Nat Rev Cancer 2011, 11:597-608.

6. Chen GG, Zeng Q, Tse GM: Estrogen and its receptors in cancer. Med Res Rev 2008, 28:954-974.

7. Ahmad N, Kumar R: Steroid hormone receptors in cancer development: a target for cancer therapeutics. Cancer Lett 2011, 300:1-9.

8. Wu CW, Lui WY, P'eng FK, Chi CW: Hormonal therapy for stomach cancer. Med Hypotheses 1992, 39:137-139.

9. Tokunaga A, Kojima N, Andoh T, Matsukura N, Yoshiyasu M, Tanaka N, Ohkawa K, Shirota A, Asano G, Hayashi K: Hormone receptors in gastric cancer. Eur J Cancer Clin Oncol 1983, 19:687-689.

10. Tokunaga A, Nishi K, Matsukura N, Tanaka N, Onda M, Shirota A, Asano G, Hayashi K: Estrogen and progesterone receptors in gastric cancer. Cancer 1986, 57:1376-1379.

11. Yokozaki H, Takekura N, Takanashi A, Tabuchi J, Haruta R, Tahara E: Estrogen receptors in gastric adenocarcinoma: a retrospective immunohistochemical analysis. Virchows Arch A Pathol Anat Histopathol 1988, 413:297-302.

12. Wu CW, Chi CW, Chang TJ, Lui WY, P'eng FK: Sex hormone receptors in gastric cancer. Cancer 1990, 65:1396-1400.

13. Sica V, Nola E, Contieri E, Bova R, Masucci MT, Medici N, Petrillo A, Weisz A, Molinari AM, Puca GA: Estradiol and progesterone receptors in malignant gastrointestinal tumors. Cancer Res 1984, 44:4670-4674.

14. Oshima CT, Wonraht DR, Catarino RM, Mattos D, Forones NM: Estrogen and progesterone receptors in gastric and colorectal cancer. Hepatogastroenterology 1999, 46:3155-3158.

15. Wu CW, Chang HM, Kao HL, Lui WY, P'eng FK, Chi CW: The nontransformed progesterone and estrogen receptors in gastric cancer. Gastroenterology 1992, 102:1639-1646.

16. Korenaga D, Orita H, Okuyama T, Kinoshita J, Maekawa S, Ikeda T, Sugimachi K: Sex hormone-receptor-negative tumors have a higher proliferative activity than sex hormone-receptor-positive tumors in human adenocarcinomas of the gastrointestinal tract. Surg Today 1998, 28:1007-1014

17. Theodoropoulos GE, Lazaris AC, Panoussopoulos D, Davaris P, Golematis BC: Significance of estrogen receptors and cathepsin $D$ tissue detection in gastric adenocarcinoma. J Surg Oncol 1995, 58:176-183.

18. Karat D, Brotherick I, Shenton BK, Scott D, Raimes SA, Griffin SM: Expression of oestrogen and progesterone receptors in gastric cancer: a flow cytometric study. Br J Cancer 1999, 80:1271-1274.

19. Matsui M, Kojima O, Kawakami S, Uehara Y, Takahashi T: The prognosis of patients with gastric cancer possessing sex hormone receptors. Surg Today 1992, 22:421-425

20. Machado JC, Carneiro F, Gärtner F, Ribeiro P, Sobrinho-Simões M: Female sex hormone receptors are not involved in gastric carcinogenesis. A biochemical and immunohistochemical study. Eur J Cancer Prev 1994, 3(Suppl 2):31-37.

21. Chaubert $P$, Bouzourene $H$, Saraga E: Estrogen and progesterone receptors and pS2 and ERD5 antigens in gastric carcinomas from the European population. Mod Pathol 1996, 9:189-193.

22. Matsuyama S, Ohkura Y, Eguchi H, Kobayashi $Y$, Akagi K, Uchida K, Nakachi K, Gustafsson JA, Hayashi S: Estrogen receptor beta is expressed in human stomach adenocarcinoma. J Cancer Res Clin Oncol 2002, 128:319-324.

23. Takano N, lizuka N, Hazama S, Yoshino S, Tangoku A, Oka M: Expression of estrogen receptor-alpha and -beta mRNAs in human gastric cancer. Cancer Lett 2002, 176:129-135.

24. Wang M, Pan JY, Song GR, Chen HB, An LJ, Qu SX: Altered expression of estrogen receptor alpha and beta in advanced gastric adenocarcinoma: correlation with prothymosin alpha and clinicopathological parameters. Eur J Surg Oncol 2007, 33:195-201.

25. Guo JL, Xu CY, Jiang ZN, Dong MJ, Xie SD, Shen JG, Cao J, Wang LB: Estrogen receptor beta variants mRNA expressions in gastric cancer tissues and association with clinicopathologic parameters. Hepatogastroenterology 2010, 57:1584-1588.

26. Xu CY, Guo JL, Jiang ZN, Xie SD, Shen JG, Shen JY, Wang LB: Prognostic role of estrogen receptor alpha and estrogen receptor beta in gastric cancer. Ann Surg Oncol 2010, 17:2503-2509.

27. Ryu WS, Kim JH, Jang YJ, Park SS, Um JW, Park SH, Kim SJ, Mok YJ, Kim CS: Expression of estrogen receptors in gastric cancer and their clinical significance. J Surg Oncol 2012, 106:456-461. 
28. Kominea A, Konstantinopoulos PA, Kapranos N, Vandoros G, Gkermpesi M, Andricopoulos P, Artelaris S, Savva S, Varakis I, Sotiropoulou-Bonikou G, Papavassiliou AG: Androgen receptor (AR) expression is an independent unfavorable prognostic factor in gastric cancer. J Cancer Res Clin Oncol 2004, 130:253-258.

29. Kononen J, Bubendorf L, Kallioniemi A, Bärlund M, Schraml P, Leighton S, Torhorst J, Mihatsch MJ, Sauter G, Kallioniemi OP: Tissue microarrays for high-throughput molecular profiling of tumor specimens. Nat Med 1998, 4:844-847.

30. Kallioniemi OP, Wagner U, Kononen J, Sauter G: Tissue microarray technology for high-throughput molecular profiling of cancer. Hum Mol Genet 2001, 10:657-662.

31. Allred DC, Clark GM, Elledge R, Fuqua SA, Brown RW, Chamness GC, Osborne CK, McGuire WL: Association of p53 protein expression with tumor cell proliferation rate and clinical outcome in node-negative breast cancer. J Natl Cancer Inst 1993, 85:200-206.

32. Raso MG, Behrens C, Herynk MH, Liu S, Prudkin L, Ozburn NC, Woods DM, Tang X, Mehran RJ, Moran C, Lee JJ, Wistuba II: Immunohistochemical expression of estrogen and progesterone receptors identifies a subset of NSCLCs and correlates with EGFR mutation. Clin Cancer Res 2009, 15:5359-5368.

33. Verma MK, Miki Y, Abe K, Niikawa H, Sasano H: Cytoplasmic estrogen receptor $\beta$ as a potential marker in human non-small cell lung carcinoma. Expert Opin Ther Targets 2012, 16(Suppl 1):S91-S102.

34. Chandanos E, Lagergren J: Oestrogen and the enigmatic male predominance of gastric cancer. Eur J Cancer 2008, 44:2397-2403.

35. Aranda A, Pascual A: Nuclear hormone receptors and gene expression. Physiol Rev 2001, 81:1269-1304.

36. Harrison JD, Morris DL, Ellis IO, Jones JA, Jackson I: The effect of tamoxifen and estrogen receptor status on survival in gastric carcinoma. Cancer 1989, 64:1007-1010.

doi:10.1186/1471-2407-12-566

Cite this article as: Gan et al:: Expression profile and prognostic role of sex hormone receptors in gastric cancer. BMC Cancer 2012 12:566.

\section{Submit your next manuscript to BioMed Central and take full advantage of:}

- Convenient online submission

- Thorough peer review

- No space constraints or color figure charges

- Immediate publication on acceptance

- Inclusion in PubMed, CAS, Scopus and Google Scholar

- Research which is freely available for redistribution 